\title{
GENETIC VARIABILITY OF HIV-1 ISOLATES FROM MINAS GERAIS, BRAZIL
}

\author{
Anna Bárbara de Freitas Carneiro Proietti ${ }^{1 *}$; Edel Figueirêdo Barbosa ${ }^{2}$; Janaína Guernica Silva ${ }^{1}$; \\ Alex Fiorini de Carvalho ${ }^{3}$; Erna Geessien Kroon ${ }^{3}$; Paulo César Peregrino Ferreira ${ }^{3}$
}

\author{
${ }^{1}$ Fundação Hemominas, Belo Horizonte, MG, Brasil. ${ }^{2}$ Laboratório de Biologia de Microrganismos \\ Intracelulares and ${ }^{3}$ Laboratório de Vírus. Departamento de Microbiologia, Universidade Federal de \\ Minas Gerais, Belo Horizonte, MG, Brasil.
}

Submitted: August 25, 1998; Returned to authors for corrections: January 28, 1999; Approved: April 20, 1999.

\section{SHORT COMMUNICATION}

\begin{abstract}
We report results of nucleotide sequencing and phylogenetic analysis of the env gene of $11 \mathrm{HIV}-1$ isolates, in Belo Horizonte, Brazil. Ten isolates belonged to HIV-1 subtype $\mathrm{B}$ and one was a probable $\mathrm{B} / \mathrm{F}$ mosaic. This putative $\mathrm{B} / \mathrm{F}$ recombinant is similar but not identical in its nucleotide sequence to other $\mathrm{B} / \mathrm{F}$ mosaics described in Brazil.
\end{abstract}

Key words: HIV-1, genome, PCR, AIDS, hemophiliacs.

Human immunodeficiency virus establishes persistent infections in humans, in most cases leading to AIDS. HIV-1 has been genetically classified into major (M) and outlier $(\mathrm{O})$ groups. The $\mathrm{M}$ group is further divided into nine subtypes (A-I), based on sequence diversity, where members of the same subtype differ in general by less than $10 \%$, and those of different subtypes by $30 \%$ or more, if env gene is analyzed $(2,4,6)$. Variation of HIV-1 can result in a spectrum of viruses exhibiting differences in cell tropism, replication, transmission rates and cytopathogenicity. At present there is considerable effort in genotyping viruses recovered from infected individuals to gain insights as to the types of viruses being transmitted in different geographical regions (6). Belo Horizonte is the third largest city in Brazil, with over 3 million inhabitants in the metropolitan area and the fourth in absolute number of AIDS cases in Brazil, as of March 1997, with over 2,400 cumulative cases (7). The objective of this work was to examine the genetic variation and the phylogenetic analysis the env gene of HIV-1 isolates of seropositive patients with history of use of clotting factor concentrates $(n=6)$, multiple transfusions $(n=1)$, heterosexual transmission $(n=3)$ and homosexual contact $(n=1)$ in Belo Horizonte, Brazil.

After informed consent, samples of peripheral blood of 11 HIV-1 seropositive patients were collected in EDTA. PBMCs (peripheral blood mononuclear cells) were separated using a FicollHypaque ${ }^{\circledR}$ gradient (Pharmacia, Sweden). Crude lysates were obtained and PCR was performed using primers encompassing the $\mathrm{C} 2-\mathrm{C} 3$ region of the env gene of HIV-1 (nested reaction). Primers were based on isolate HXB2 genome (GenBank accession number KO3455), and were provided by the World

\footnotetext{
* Corresponding author. Mailing address: Fundação Centro de Hematologia e Hemoterapia de Minas Gerais - Hemominas, Alameda Ezequiel Dias, 321, Santa Efigênia, CEP 30130-110, Belo Horizonte, MG, Brazil. Fax (+5531) 226-2002. E-mail: arraia@gold.com.br
} 
Health Organization (WHO). The first round reactions of the env gene were performed using primers ED3/ED14, corresponding to positions 5956-5985 and 7960-7931, which amplified a 2.0 $\mathrm{Kb}$ fragment. The nested reactions were done with primers ED31/ ED33, corresponding to positions 6816-6844 and 7359-7380, producing a $0.5 \mathrm{~Kb}$ fragment (region $\mathrm{C} 2-\mathrm{C} 3$ ). Nucleotide sequencing (Sequenase ${ }^{\circledR}$, USB, USA) was performed directly on DNA amplified by PCR of the PBMC lysates, using the primers ED31, ED33 and ES7 (C2-V3 region). Nucleotide sequences were obtained from both strands and each was done at least twice, using the dideoxi termination method (9). Sequences were aligned using Clustal W. Pairwise distance methods, using the Jukes and Cantor correction and bootstrap analysis, were performed for phylogenetic inference, with the package Treecon 3.1 for Windows (10).

HIV-1 env sequences obtained from Belo Horizonte isolates clustered with isolates of subtype
B in the phylogenetic analysis performed (Fig. 1). These results are in concordance with env heteroduplex mobility assays (HMA) (1) results of the same samples, except for an isolate from an asymptomatic blood donor (BHGM19), whose HMA results showed $\mathrm{F}$ subtype mobility, but whose $\mathrm{C} 2 \mathrm{~V} 3$ env sequences clustered consistently with subtype B. This discordant branching has been reported before in an isolate from São Paulo, Brazil (93BR019), which was a mosaic of subtypes B and F (8).

In nine of eleven env amino acid sequences, the tetrameric subdomain at the crown of V3 loop (Table 1) had the sequence GPGR, including the $B / F$ isolate (BHGM19, blood donor, heterosexual transmission), whose crown had the sequence HIGPGRAF, identical to previously described and independently collected $\mathrm{F}$ subtype isolates from other cities in Brazil $(3,5)$. One isolate (JS, hemophiliac patient) had the GPGQ sequence, which is common in subtypes A,

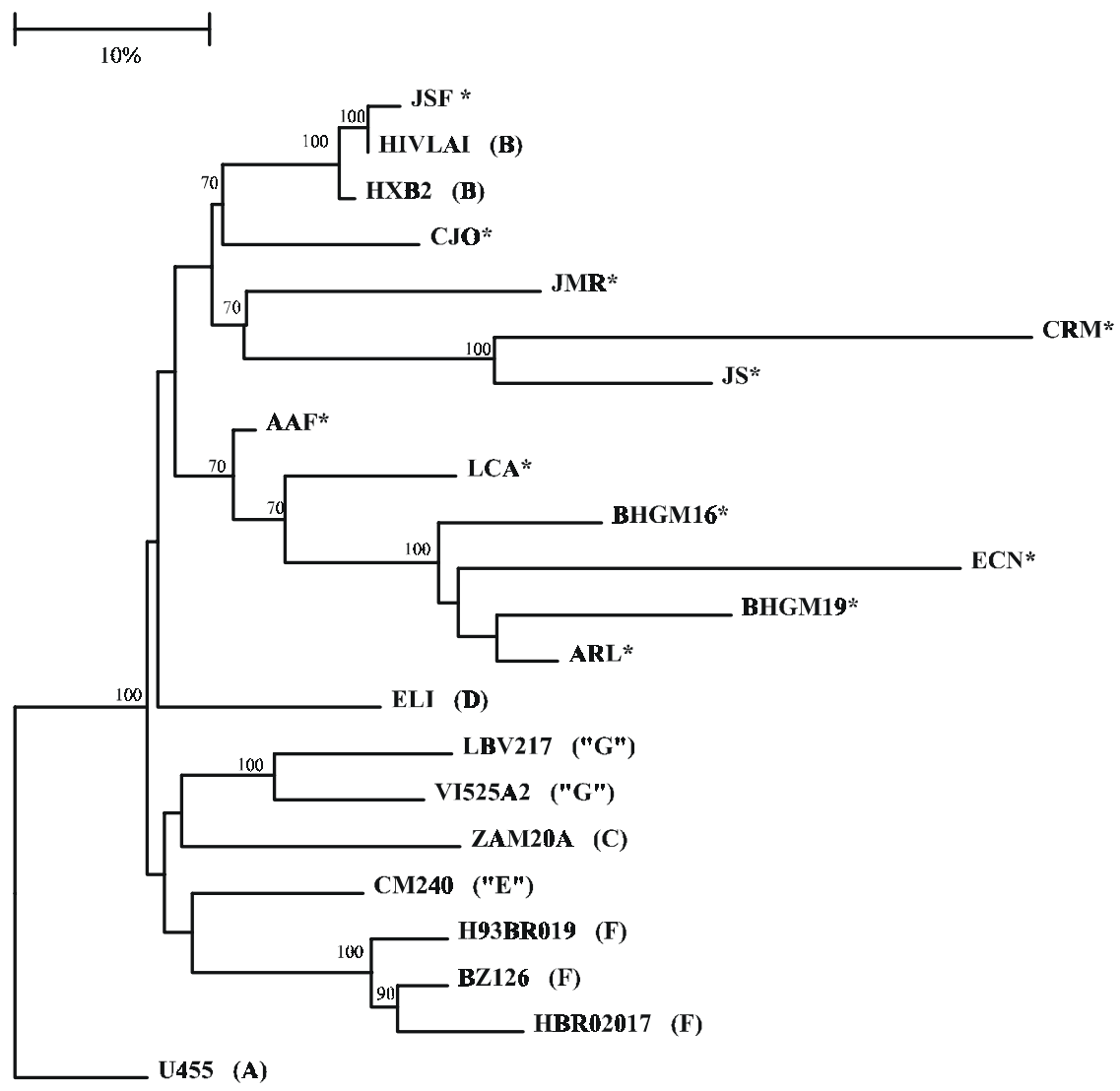

Figure 1 - Phylogenetic relationships of the sequences of the C2V3 region of HIV-1 env gene of isolates from Minas Gerais (asterisks), compared to sequences representative of subtypes A-G. Isolate U455 was chosen arbitrarily to root the tree. Quotes indicate "mosaic" subtypes. Values at the nodes represent bootstraps analysis (shown only values above 75\%). 
$\mathrm{C}$ and $\mathrm{E}$ isolates and one (JMR, heterosexual transmission) had the sequence GPGK, rarely reported in subtype $\mathrm{B}$. The five cysteine residues of the $\mathrm{C} 2-\mathrm{V} 3$ region were conserved in all isolates, including the ones at the base of $\mathrm{V} 3$ loop $(\mathrm{C} 1$ and C35).

Table 1 - Aminoacid sequences of the V3 crown of HIV-1 env gene and risk factor in 11 seropositive patients, Belo Horizonte, Minas Gerais, 1997.

\begin{tabular}{|c|c|c|}
\hline Patient & $\begin{array}{c}\text { V3 Loop } \\
\text { Crown Sequences }\end{array}$ & $\begin{array}{l}\text { Probable mode } \\
\text { of transmission }\end{array}$ \\
\hline $\mathrm{ECN}$ & GPGR & Hemophiliac patient $^{1}$ \\
\hline CJO & GPGR & Hemophiliac patient $^{1}$ \\
\hline JSF & GPGR & Homosexual transmission \\
\hline CRM & GPGR & Hemophiliac patient $^{1}$ \\
\hline $\mathrm{AAF}$ & GPGR & Transfusion ${ }^{2}$ \\
\hline ARL & GPGR & Hemophiliac patient $^{1}$ \\
\hline GM16 & GWGR & Heterosexual transmission \\
\hline GM19 & GPGR & Heterosexual transmission \\
\hline JS & GPGQ & Hemophiliac patient $^{1}$ \\
\hline JMR & GPGK & Heterosexual transmission \\
\hline LCA & GPGR & Hemophiliac patient $^{1}$ \\
\hline
\end{tabular}

${ }^{1}$ Use of clotting factor concentrates

${ }^{2}$ Use of packed red blood cells

All the isolates in this study, with one exception, belonged to HIV-1 subtype B, which is the most prevalent in the United States and Europe. The exception was a probable $\mathrm{B} / \mathrm{F}$ mosaic. This putative B/F recombinant from Belo Horizonte (BHGM19) is similar, but not identical in its nucleotide sequence to other $\mathrm{B} / \mathrm{F}$ mosaics described in Brazil $(3,5,8)$. Sequencing of additional regions of these viruses may help to understand the recombination events that took place to generate these chimeric genomes.

GeneBank accession numbers: AF025918 to AF025926; U46210; U46122

\section{ACKNOWLEDGMENTS}

The present work was supported by Fapemig, Capes and CNPq. The authors thank Drs. Yves Van de Peer, Keith Peden and Phoebe Mounts for their support and helpful suggestions.

\section{RESUMO}

\section{Variabilidade genética de isolados de HIV-1 em Minas Gerais, Brasil}

Relatamos resultados do estudo de seqüência de nucleotídeos e análise filogenética do gene env 11 isolados HIV-1 em Belo Horizonte, Brasil. Dez isolados pertenciam ao subtipo $\mathrm{B}$ e um era provavelmente um mosaico B/F. Este possível recombinante $\mathrm{B} / \mathrm{F}$ é similar, mas não idêntico, em sua seqüência de nucleotídeos, aos demais mosaicos $\mathrm{B} / \mathrm{F}$ descritos no Brasil.

Palavras-chave: HIV-1, genoma, PCR, AIDS, hemofílicos.

\section{REFERENCES}

1. Delwart, E.L.; Mullins, J.I. A DNA heteroduplex gel shift assay for the analysis of HIV sequence diversity. Science, 262:1257-61,1993.

2. Louwagie, J.; Janssens, W.; Mascola, J.; Heyndrickx, L.; Hegerich, P.; Van Der Groen, G.; McCutchan, F.E.; Burke, D.S. Genetic diversity of the envelope glycoprotein from human immunodeficiency virus type 1 isolates of African origin. J Virol. 69:263-71, 1993.

3. Louwagie, J.; Delwart, E.L.; Mullins, J.I.; McCutchan, F.E.; Eddy, E., Burke; D.S. Genetic analysis of HIV isolates from Brazil reveals presence of two distinct genetic subtypes. AIDS Res. Hum. Retroviruses, 10:561-7, 1994.

4. McKeating J.A; Biological consequences of human immunodeficiency virus type 1 envelope polymorphism: does variation matter? J. Gen. Virol. 77:2905-19, 1996.

5. Morgado, M.G.; Sabino, E.C.; Shpaer, E.G.; Bongertz, V.; Brigido, L.; Guimarães, M.D.C.; Castilho, E.A.; GalvãoCastro, B.; Mullins, J.I.; Hendry, R.M.; Mayer A. V3 region polymorphisms in HIV-1 from Brazil: prevalence of subtype B strains divergent from North American/European prototype and detection of subtype F. AIDS Res. Hum. Retroviruses, 10:569-76, 1994.

6. Myers, G. HIV: between past and future. AIDS Res. Hum. Retrov. 10:1317-24,1994.

7. Programa Nacional de Doenças Sexualmente Transmissíveis/ AIDS. Boletim Epidemiológico/AIDS; 5: 31, 1997.

8. Sabino, E.C.; Shpaer, E.G.; Morgado, M.G.; Korber, B.T.M.; Diaz, R.S.; Bongertz, V.; Cavalcante, S.; Galvão-Castro, B.; Mullins, J.I.; Mayer, A. Identification of human immunodeficiency virus type 1 envelope genes recombinant between subtypes $\mathrm{B}$ and $\mathrm{F}$ in two epidemiologically linked individuals from Brazil. J. Virol., 68:6340-6, 1994.

9. Sambrook, J.; Fritsch, E.F.; Maniatis, T. Molecular Cloning. A Laboratory Manual. New York: Cold Spring Harbor Laboratory Press, 1989.

10. Van de Peer, Y.; De Wachter, R. Treecon for Windows: a software package for the construction and drawing of evolutionary trees for the Microsoft Windows environment. Comput. Applic. Biosci., 10: 569-70, 1994. 